\title{
Steroidal and Triterpenoidal Fungal Metabolites as Ligands of Liver X Receptors
}

\author{
John G. Ondeyka, Hiranthi Jayasuriya, Kithsiri B. Herath, Ziqiang Guan, Marvin Schulman, \\ Javier Collado, Anne W. Dombrowski, Soojin S. Kwon, Christine McCallum, Neelam Sharma, \\ Karen MacNaul, Nancy Hayes, John G. Menke, Sheo B. Singh
}

Received: July 19, 2005 / Accepted: August 19, 2005

(C) Japan Antibiotics Research Association

\begin{abstract}
Cholesterol homeostasis is tightly controlled process that involves a variety of regulators including liver $X$ receptors (LXR). Agonists of $\mathrm{LXR}$ are expected to increase cholesterol efflux, lower LDL, and raise HDL levels. Screening of a natural product library of microbial extracts using a LXR-scintillation proximity assay (SPA) binding assay and bioassay-guided fractionation of a number of fungal extracts led to the isolation of five ergostane and a cycloartane derivative. These compounds exhibited $\mathrm{IC}_{50}$ value ranging $0.5 \sim 9 \mu \mathrm{M}$ in the binding assay for $\alpha$-receptor and a number of these showed in vitro agonist activity in the coactivator association assays but lacked the cell based LXR activation. The isolation and LXR activity of these compounds are described.
\end{abstract}

Keywords steroids, triterpenoids, LXR receptor agonists, microbial products, cholesterol lowering agents

\section{Introduction}

Liver X receptors (LXR) are members of a superfamily of nuclear hormone receptors. There are two subtypes of these receptors, $\operatorname{LXR} \alpha$ and $\operatorname{LXR} \beta[1 \sim 3]$. They play a role in cholesterol homeostasis [4]. The $\alpha$-subtype is predominantly found in the liver whereas the $\beta$-subtype is ubiquitously expressed. Oxysterols have been identified as endogenous ligands for both LXR subtypes [5 8]. LXR receptors form heterodimers with the retinoid $\mathrm{X}$ receptor
(RXR) and regulate the expression of a number of genes involved in cholesterol and fatty acid metabolism including adenosine friphosphate binding cassette frasporter A1 (ABCA1). ABCA1 mediates the efflux of cholesterol from the cell and onto the apolipo protein (Apo) A1 protein of HDL particles. Nonsteroidal agonists of LXR that increased the expression levels of ABCA1 raised the HDL levels in mice [9]. Therefore, LXR agonists are expected to provide an opportunity for the development of drugs to increase reverse cholesterol transport and thus decrease the burden of atherosclerosis [4].

Recently we reported a number of structurally diverse natural products as LXR ligands derived from plants [10 12], and a Streptomyces sp. [13] Continued screening of a microbial extract library employing the ligand binding domain of $\operatorname{LXR} \alpha$ and $\beta$ receptor using radioactive ligand and scintillation proximity binding assays (LXR-SPA) [14] allowed identification of a number of extracts that exhibited binding inhibitory activities. Standardized bioassay-guided fractionation of these extracts led to the isolation of ergostane derivatives: ergosterol, $\mathbf{2}$ and $\mathbf{3}$ from Tolypocladium niveum, 4 from Colletotrichum dematium and 5 from Acremonium sordidulum and a cycloartane derivative 7, from an unidentified fungus. These compounds inhibited LXR activities to different degrees with $\mathrm{LXR} \alpha$ binding $\mathrm{IC}_{50}$ ranges of $0.5 \sim 6.5 \mu \mathrm{M}$. The isolation, structure, LXR binding and agonist activities are detailed herein.
S. B. Singh (Corresponding author), J. G. Ondeyka, H. Jayasuriya, K. B. Herath, Z. Guan, M. Schulman, J. Collado, A. W. Dombrowski, S. S Kwon, C. McCallum, N. Sharma, K.
MacNaul, N. Hayes, J. G. Menke: Merck Research Laboratories, P. O. Box 2000, Rahway, New Jersey 07065, E-mail: sheo_singh@merck.com 


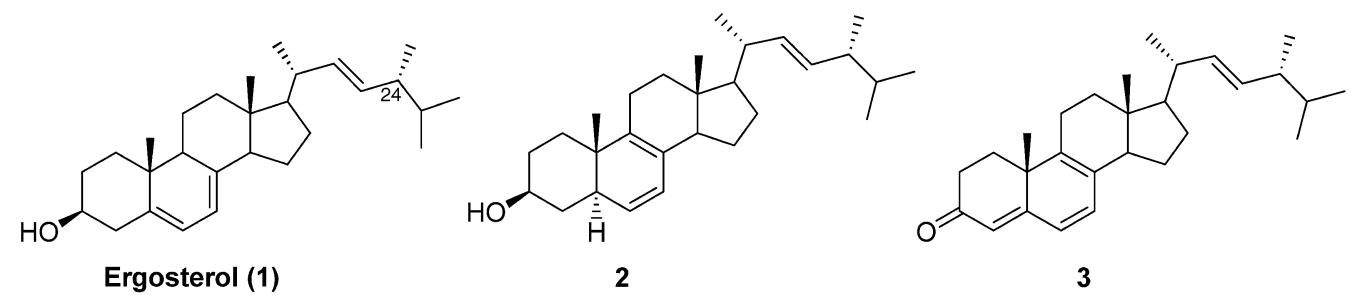<smiles>Cc1cc2c(c3c1CC[C@@H](O)C3)C1CC[C@H]([C@H](C)/C=C/[C@H](C)C(C)C)[C@]1(C)CC2</smiles><smiles>CC(C)[C@H](C)/C=C/[C@H](C)C1CCC2C3=C(CC[C@@]21C)[C@@]1(C)CC[C@@H](O)CC1=CC3O</smiles>

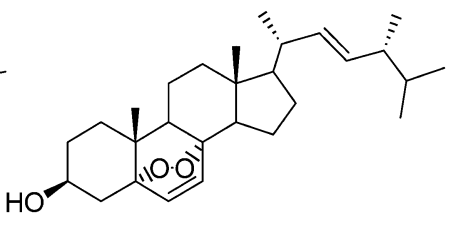

Ergosterol peroxide (6)

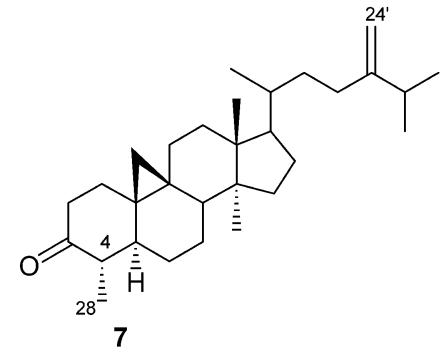

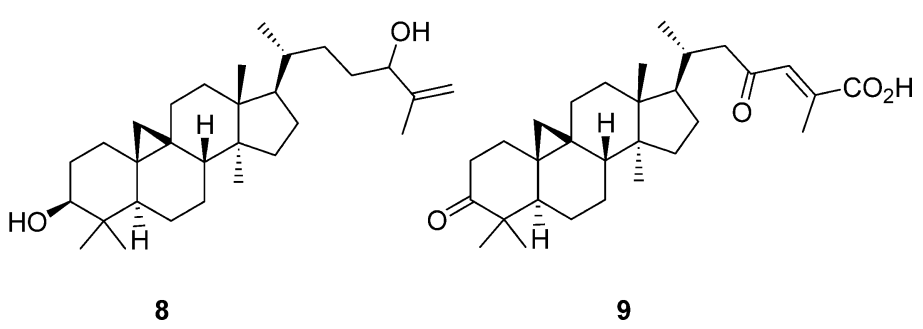

Fig. 1 Chemical structures of compounds 1-9.

\section{Results and Discussion}

\section{Compounds 2 and 3}

These two ergostane derivatives along with ergosterol (1) were isolated from the fermentation broth of Tolypocladium niveum collected from Puerto Rico. Sephadex LH 20 followed by two steps of reversed phase HPLC and silica gel chromatographies afforded the three compounds. The production of ergosterol (1) was substantially higher than $\mathbf{2}$ and the enone $\mathbf{3}$. The structure of ergosterol was confirmed by direct comparison with an authentic sample. The structure of 3 (MW 392) was elucidated as ergostan-4,6,8,22-tetraen-3-one by the comparison of published spectroscopic data of the compound originally reported from the oyster fungus, Pleurotus ostreatus [15]. Mass spectral analysis of 2 produced a molecular ion at $\mathrm{m} / \mathrm{z} 396$ suggesting the presence of 4 extra hydrogen atoms. ${ }^{1} \mathrm{H}$ NMR spectrum of $\mathbf{2}$ was similar to the spectrum of $\mathbf{3}$ except for the absence of the enone proton and the presence of methine at C-3 $\left(\delta_{\mathrm{H}} 3.71, \mathrm{~m}\right)$ indicating that this compound was ergostan-6,8,22-trien-3-ol which has been reported from soil amoebae, Acanthamoeba polyphaga, Neaegleria lovaniensis and $N$. gruberi and was characterized as a mono acetate [16 18]. The ${ }^{1} \mathrm{H}$ NMR data of this compound is reported here for the first time and is consistent with the ${ }^{1} \mathrm{H}$
NMR spectral data of the acetate $[16,18]$ except for the acetate induced changes.

\section{Compound 4}

Colletotrichum dematium, the fungus that produced 4, was isolated from Monotropa uniflora collected in New Jersey. The strain was cultured in a liquid media and extracted with MEK. Sephadex LH 20 chromatography followed by two successive steps of reversed phase HPLC afforded $12.7 \mathrm{mg}$ of 4 (MW 394). The structure of 4 was elucidated by 2D NMR spectroscopy as ring $B$ aromatic steroid with the migration of C-10 methyl group to C-6. The structure was confirmed by comparison of the published data of the compound isolated from soil amoeba Acanthamoeba polyphaga [19].

\section{Compound 5}

This compound was produced by a fungal strain identified as Acremonium sordidulum isolated from sand collected at a beach in Puerto Rico and was grown on FFL medium. It was isolated from a MEK extract of the fermentation broth after Sephadex LH 20 and silica gel TLC affording 5 (1 mg, $33 \mathrm{mg} /$ liter). 5 was characterized by mass and 2D NMR spectral analysis. While the $7 R$ analog was prepared in $6 \sim 9 \%$ yield from ergosterol (1) by in vitro singlet oxygen reaction [20] this is first report of this compound from nature. This broth also produced small amounts of 
Table 1 LXR activities of steroids and triterpenoids (1 $\sim 7)$ and comparator compounds

\begin{tabular}{|c|c|c|c|c|c|c|}
\hline \multirow{2}{*}{ Compound } & \multicolumn{2}{|c|}{$\begin{array}{l}\text { LXR SPA binding } \\
\qquad \mathrm{IC}_{50}(\mu \mathrm{M})\end{array}$} & \multicolumn{2}{|c|}{$\begin{array}{l}\text { Coactivator association } \\
\text { HTRF assay, } \mathrm{EC}_{50}(\mu \mathrm{M})\end{array}$} & \multicolumn{2}{|c|}{$\begin{array}{l}\text { Transactivation max } \\
\text { fold induction }\end{array}$} \\
\hline & $\operatorname{LXR} \alpha$ & $\operatorname{LXR} \beta$ & $\operatorname{LXR} \alpha$ & $\operatorname{LXR} \beta$ & $\operatorname{LXR} \alpha$ & $\operatorname{LXR} \beta$ \\
\hline Ergosterol (1) & 6.5 & - & - & - & - & - \\
\hline 2 & 2.8 & - & - & - & - & - \\
\hline 3 & 2.3 & $>15$ & 1.0 & $>50$ & - & - \\
\hline 4 & 9.0 & 1.3 & $1.96^{*}$ & $>50$ & NA & NA \\
\hline 5 & 2.3 & - & - & - & - & - \\
\hline Ergosterol peroxide (6) & 1.6 & $>50$ & 1.7 & - & NA & - \\
\hline 7 & 0.5 & 1.0 & $>10$ & $>50$ & NA & NA \\
\hline 8 & 1.2 & NT & NT & NT & NT & NT \\
\hline 9 & 1.7 & NT & NT & NT & NT & NT \\
\hline$\left[{ }^{3} \mathrm{H}_{2}\right]-\mathrm{F}_{3}$-methyl AA & 0.035 & 0.025 & 0.035 & 0.016 & 20 & 35 \\
\hline 22-(R)-OH-cholesterol & $70 \% @ 100 \mu \mathrm{M}$ & $60 \% @ 100 \mu \mathrm{M}$ & $>15$ & $>15$ & 4 & 8 \\
\hline
\end{tabular}

Blank space (Not Tested), NA (not active at $10 \mu \mathrm{M})$, * Partial agonist max $36 \%$

compound 4 .

\section{Cycloeucalenone (7)}

It was isolated from an unidentified fungus collected from New Jersey. Extraction with MEK and Sephadex LH 20 and two successive steps of reversed phased chromatographies afforded 7 (14 mg, $35 \mathrm{mg} / \mathrm{liter})$. The structure of 7 was elucidated as cycloeucalenone (24methyl-29-norcycloart-24(24')-en-3-one) by ESIMS (MW 424) and comparison of NMR spectral data with the published data. Both $\alpha$ and $\beta$ isomers of $\mathrm{C}-4$ have been reported [21, 22]. The ${ }^{1} \mathrm{H}$ NMR spectrum of 7 exhibited a doublet of doublets at $\delta_{\mathrm{H}} 2.41$ with $J_{4,5}=14 \mathrm{~Hz}$ and $J_{4,28}=6 \mathrm{~Hz}$ suggesting an anti-relationship of $\mathrm{H}-4$ and $\mathrm{H}-5$ and establishing $\mathrm{H}_{\beta}$ at $\mathrm{C}-4$. Both cycloeucalenone (7) and 4-epicycloeucalenone were originally isolated from a banana peel, Musa sapientum and this is first report of its production by fungal species.

\section{LXR Activity}

Compounds were first evaluated for their ability to displace the tritiated ligand $\left\{\left[{ }^{3} \mathrm{H}_{2}\right]-\mathrm{F}_{3}\right.$-methyl AA \{3-chloro-4-(3-(7(2,3-ditritio-propyl)-3-trifluoromethyl-6-(4,5)-isoxazolyl)propylthio)-phenyl acetic acid $\}$ in the LXR-SPA receptor binding assays using ligand binding domains (LBD) of $\alpha$ and $\beta$ LXR and the results are expressed as $\mathrm{IC}_{50}$ (concentration of compound required to exhibit $50 \%$ displacement of the radio ligand) [14]. Following the measurements of the binding activity, many of these compounds were further evaluated for their functional activity in a coactivator association and transactivation assays. The coactivator association assay determines the association of recombinant steroid receptor coactivator 1 (SRC1) protein with recombinant LXR $\alpha$ and $\beta$ LBD using homogeneous time resolved fluorescence (HTRF) detection method and results are expressed as $\mathrm{EC}_{50}$ (effective concentration of compound requiring $50 \%$ stimulation of coactivator association). The transactivation assay determines the activation of receptors expressed in HEK293 cells and data is expressed as fold induction compared to DMSO control [14].

Of the ergosterol (1) series, the B-ring $\Delta^{6,8}$-diene 2 exhibited LXR $\alpha$ binding affinity with an $\mathrm{IC}_{50}$ of $2.8 \mu \mathrm{M}$ whereas the isomer, ergosterol (1), with $\Delta^{5,7}$-diene was 2 fold less active and exhibited binding affinity with $\mathrm{IC}_{50}$ of $6.5 \mu \mathrm{M}$. The trienone 3 showed slightly better affinity for the $\alpha$-receptor $\left(\mathrm{IC}_{50} 2.3 \mu \mathrm{M}\right)$. Of the three non-aromatic mono-oxygenated ergosterol derivatives the better of the three compounds, 3 was further evaluated. It did not show any binding to $\operatorname{LXR} \beta\left(\mathrm{IC}_{50}>15 \mu \mathrm{M}\right)$. In coactivator association assays, it was an agonist of $\operatorname{LXR} \alpha$ and stimulated the $\alpha$-receptor with $\mathrm{EC}_{50}$ value of $1 \mu \mathrm{M}$ and was not effective for the $\beta$-receptor. The B-ring aromatic compound 4 exhibited better binding inhibition for $\operatorname{LXR} \beta$ $\left(\mathrm{IC}_{50} 1.3 \mu \mathrm{M}\right)$ compared to $\operatorname{LXR} \alpha\left(\mathrm{IC}_{50} 9 \mu \mathrm{M}\right)$. It was a partial agonist (36\% maximal stimulation) of the $\alpha$ receptor $\left(\mathrm{EC}_{50} 1.96 \mu \mathrm{M}\right)$ as measured by coactivator association assays and was not effective for $\operatorname{LXR} \beta$ (EC $\left.\mathrm{E}_{50}>50 \mu \mathrm{M}\right)$. Of the mono-oxygenated compounds, 4 was tested in the transactivation assay. This compound did 
not show any activity in the transactivation assay at $10 \mu \mathrm{M}$. Of the two di- and tri-oxygenated ergosterol derivatives, $\mathbf{5}$ and ergosterol peroxide, showed binding affinities to LXR $\alpha$ with $\mathrm{IC}_{50}$ of 2.3 and $1.6 \mu \mathrm{M}$, respectively. Ergosterol peroxide did not have any effect on the binding affinity for LXR $\beta$. It exhibited LXR $\alpha$ agonist activity $\left(\mathrm{EC}_{50} 1.7 \mu \mathrm{M}\right)$ in the coactivator association assay. However it had no effect on the transactivation activity at $10 \mu \mathrm{M}$.

The 29-nor-cycloartane derivative, cycloeucalenone (7) displayed the best binding affinity of all with $\mathrm{IC}_{50}$ values of 0.5 and $1.0 \mu \mathrm{M}$, respectively, for $\operatorname{LXR} \alpha$ and $\beta$ exhibiting $2 \sim 3$ fold better affinity for $\operatorname{LXR} \alpha$ than plant derived cycloartanes $(\mathbf{8}, 9)$ [12] suggesting a positive role played by either addition of the methyl group at C-24 or subtraction of the C-29 methyl group. However, this compound was not an agonist at $>10 \mu \mathrm{M}$ against either of the two receptors and was not effective in the transactivation assays.

It has been reported that cholesterol and a number of hydroxy cholesterol derivatives such as $7 \alpha$, and $22 S$-, have no effect on the LXR activation and others such as $20 S$-, $22 R$-, 24R-, 24S-, 25-, 27-hydroxy, 24R, 25 and 24S,25epoxy, and 24-keto cholesterol have varying degree of receptor activation $[6 \sim 8,23]$.

In summary, we have described the isolation and LXR activities of a number of unsaturated steroids of ergosterol and 29-nor-cycloartane families. While a number of oxycholesterols are natural agonists of LXR receptors, the activity of these compounds adds to the growing reservoir of understanding of LXR receptor binding.

\section{Experimental}

\section{General Experimental Procedures}

All ACS grade solvents were obtained from Fisher Scientific. Optical rotations were measured on a PerkinElmer 241 polarimeter. The UV spectra were recorded in $\mathrm{MeOH}$ on a Beckman DU-70 Spectrophotometer. IR spectra were recorded on Perkin-Elmer Spectrum One spectrometer. HRESIMS were obtained on a Thermo Quest FTMS spectrometer using electrospray ionization. The NMR spectra were recorded on a Varian INOVA 400 or 500 FTNMR spectrometers at 400 or $500 \mathrm{MHz}$ for ${ }^{1} \mathrm{H}$ and 100 or $125 \mathrm{MHz}$ for ${ }^{13} \mathrm{C}$ in $\mathrm{CDCl}_{3}$. Agilent $\mathrm{HP} 1100$ was used for analytical HPLC.

\section{Seed Media}

KFA in $\mathrm{g} /$ liter of distilled water: corn steep liquor (5), tomato paste (40), oat flour (10), glucose (10), trace elements, agar (4) in distilled water at $\mathrm{pH}$ 6.8. YMEJ in $\mathrm{g} /$ liter of distilled water: yeast extract (4), malt extract (8), glucose (4), junlon (1.5), $\mathrm{pH}$ adjusted to 7.0.

\section{Production Media}

DEF2: This liquid medium consists of three solutions that are prepared and mixed at different proportions. Solution A consists of in $\mathrm{g} / 900 \mathrm{ml}$ distilled water: glycerol (60), mono sodium glutamate (10), L-tryptophan (0.7), $\mathrm{NH}_{4} \mathrm{Cl}$ (3), $\mathrm{K}_{2} \mathrm{HPO}_{4}(1), \mathrm{CaCO}_{3}(1), \mathrm{MgSO}_{4} \cdot 7 \mathrm{H}_{2} \mathrm{O}(0.58)$, MES (20), salts $(20 \mathrm{ml}), \mathrm{pH}$ adjusted to 6.0 by addition of $\mathrm{NaOH}$. Solution B in $\mathrm{g} / 100 \mathrm{ml}$ distilled water: glucose (60) and autoclave. Solution 3 salts in $\mathrm{mg} /$ liter: $\mathrm{FeSO}_{4} \cdot 7 \mathrm{H}_{2} \mathrm{O}(500)$, $\mathrm{ZnSO}_{4} \cdot 7 \mathrm{H}_{2} \mathrm{O}(500), \mathrm{MnSO}_{4} \cdot \mathrm{H}_{2} \mathrm{O}(100), \mathrm{CuSO}_{4} \cdot 5 \mathrm{H}_{2} \mathrm{O}$ (50), $\mathrm{CoCl}_{2} \cdot 6 \mathrm{H}_{2} \mathrm{O}$ (40), conc. $\mathrm{HCl}(50 \mathrm{ml} /$ liter). A $45 \mathrm{ml}$ aliquot of solution 1 was added to a $250 \mathrm{ml}$ flask followed by $5 \mathrm{ml}$ of solution 2 and $20 \mathrm{ml}$ of salts. NPF 2 medium, components in $\mathrm{g} /$ liter of distilled water: glucose (150), urea (4), N. Z. amine type A (4), $\mathrm{K}_{2} \mathrm{HPO}_{4}(0.5), \mathrm{MgSO}_{4} \cdot 7 \mathrm{H}_{2} \mathrm{O}$ (0.25), $\mathrm{KCl}(0.25), \mathrm{ZnSO}_{4} \cdot 7 \mathrm{H}_{2} \mathrm{O}(0.9), \mathrm{CaCO}_{3}$ (16.5) without any $\mathrm{pH}$ adjustment. FFL medium, components in g/liter in distilled water: glycerol (100), glucose (70), Ltryptophan (0.7), $\mathrm{NH}_{4} \mathrm{Cl}$ (3), mono sodium glutamate (10), amicase (8), MES (20), $\mathrm{K}_{2} \mathrm{HPO}_{4}(1), \mathrm{MgSO}_{4} \cdot 7 \mathrm{H}_{2} \mathrm{O}(0.5)$, $85 \%$ lactic acid $(5 \mathrm{ml})$, trace elements $(20 \mathrm{ml})$, adjust $\mathrm{pH}$ to 6.0 before addition of $\mathrm{CaCO}_{3}(1 \mathrm{~g})$.

\section{Fermentation and Isolation of $\mathbf{2}$ and 3}

The producing organism a fungus, Tolypocladium niveum (JP3248) was isolated from leaf litter of Guare guidonia collected from Puerto Rico and grown on a YMEJ seed medium for 3 days at $25^{\circ} \mathrm{C}$ followed by a transfer and growth on a production medium NPF2 for 18 days at $22^{\circ} \mathrm{C}$ in a $250 \mathrm{ml}$ Erlenmeyer flask containing $50 \mathrm{ml}$ of the medium. 2 liters fermentation broth was extracted with 2 liters MEK by shaking for 1 hour. The extract was concentrated to dryness affording $2.1 \mathrm{~g}$ residue which was chromatographed on a 1.5 liters Sephadex LH 20 in methanol. The active fractions were pooled which contained a large amounts of ergosterol which was collected by filtration and a $50 \mathrm{mg}$ portion was chromatographed on a Zorbax $\mathrm{RX} \mathrm{C}_{8}(21 \times 250 \mathrm{~mm})$ column eluting with a 50 minutes gradient of $40 \sim 90 \%$ aqueous $\mathrm{CH}_{3} \mathrm{CN}+0.1 \%$ TFA followed by holding at $90 \%$ for 25 minutes then at $99 \%$ at a flow rate of $8 \mathrm{ml} /$ minute. The fractions eluting at 88 minutes was concentrated to give $22 \mathrm{mg}$ of mixture and purified by preparative TLC on silica gel $(3 \% \mathrm{MeOH}$ $\mathrm{CH}_{2} \mathrm{Cl}_{2}$ ). Compounds eluting at $\mathrm{Rf}$ values of $\sim 0.5 \sim 7$ $(8 \mathrm{mg}$ ) was rechromatographed on a semi prep Zorbax RX $\mathrm{C}_{8}(9.4 \times 250 \mathrm{~mm})$ eluting with $85 \%$ aqueous $\mathrm{CH}_{3} \mathrm{CN}+0.1 \%$ TFA at a flow rate of $4 \mathrm{ml} /$ minute. The major compound 2 $(3 \mathrm{mg})$ eluted at 29 minutes and the minor compound 3 $(1 \mathrm{mg})$ eluted at 40 minutes which were lyophilized to give 
colorless powder. 2: ${ }^{1} \mathrm{H}$ NMR $\left(\mathrm{CDCl}_{3}\right) \delta 0.68\left(3 \mathrm{H}, \mathrm{s}, \mathrm{H}_{3}-\right.$ 19), 0.86 and 0.87 ( $3 \mathrm{H}$ each, d, $\left.J=6.5 \mathrm{~Hz}, \mathrm{H}_{3}-26,27\right), 0.94$ (3H, s, $\left.\mathrm{H}_{3}-18\right), 0.95$ (3H, d, $\left.J=6.5 \mathrm{~Hz}, \mathrm{H}_{3}-21\right), 1.07$ (3H, d, $\left.J=6.5 \mathrm{~Hz}, \mathrm{H}_{3}-28\right), 1.17 \sim 1.35(4 \mathrm{H}, \mathrm{m}), 1.37 \sim 1.54(6 \mathrm{H}, \mathrm{m})$, $1.70 \sim 2.0(5 \mathrm{H}, \mathrm{m}), 2.0 \sim 2.15(3 \mathrm{H}, \mathrm{m}), 2.25 \sim 2.42(2 \mathrm{H}, \mathrm{m})$, $3.72(1 \mathrm{H}, \mathrm{m}, \mathrm{H}-3), 5.23$ and $5.26(1 \mathrm{H}$ each, dd, $J=15,7 \mathrm{~Hz}$, H-22 and H-23), 5.29 (1H, br d, $J=9.5 \mathrm{~Hz}, \mathrm{H}-7), 6.15(1 \mathrm{H}$, dd, $J=10,3 \mathrm{~Hz}, \mathrm{H}-6)$; ESIMS $(m / z) 397(\mathrm{M}+\mathrm{H})$.

\section{Fermentation and Isolation of 4}

The producing organism a fungus, Colletotrichum dematium (GB4417) was a single spore isolated from sporodochia formed on stems of Monotropa uniflora, collected in Califon, New Jersey. Inoculum was grown on YMEJ medium and then the cells were used to inoculate NPF2 media at the condition described for $\mathbf{3}$ and $\mathbf{2}$ except for harvesting after 21 days. A 2 liters fermentation broth was extracted with 2 liters MEK and concentrated to give $2 \mathrm{~g}$ which was dissolved in $30 \mathrm{ml} \mathrm{MeOH}$ and chromatographed on 1 liter of Sephadex LH 20 in $\mathrm{MeOH}$ to give an active fraction weighing $300 \mathrm{mg}$. A $2 / 3 \mathrm{rd}$ portion of the fraction was chromatographed on a reversed phase Zorbax $\mathrm{RX} \mathrm{C}_{8}(21 \times 250 \mathrm{~mm})$ column with a 30 minutes gradient of 20 to $80 \%$ aqueous $\mathrm{CH}_{3} \mathrm{CN}$ with a hold for 20 minutes at a flow rate of $8 \mathrm{ml} / \mathrm{minute}$. The active fraction (30 mg) eluted in $80 \%$ of $\mathrm{CH}_{3} \mathrm{CN}$ at $46 \sim 50$ minutes was rechromatographed on same HPLC column using a 30 minutes gradient of $80 \sim 90 \%$ aqueous $\mathrm{CH}_{3} \mathrm{CN}$ at a flow rate of $8 \mathrm{ml} /$ minute. Fractions eluting at $21 \sim 25$ minutes were pooled and lyophilized to give $12.7 \mathrm{mg}$ of $\mathbf{4}$ as a gum.

\section{Fermentation and Isolation of 5}

The producing fungus, Acremonium sordidulum (F094151), was recovered from sand collected at a beach in Puerto Rico. For the production of the compound, seed flasks of KF seed medium were prepared from a fresh slant culture on potato dextrose agar (Difco), as described [24]. Two milliliter aliquots of the seed cultures were used to inoculate $250 \mathrm{ml}$ unbaffled Erlenmeyer flasks containing $50 \mathrm{ml}$ of FFL production medium. The production flasks were incubated at $22^{\circ} \mathrm{C}$ in a rotatory shaker at $220 \mathrm{rpm}$ for 20 days. A $30 \mathrm{ml} \mathrm{MEK} \mathrm{extract} \mathrm{was} \mathrm{chromatographed} \mathrm{on}$ $70 \mathrm{ml}$ Sephadex LH 20 in $\mathrm{MeOH}$ and the active fraction (10 mg) was chromatographed on silica gel TLC $(5 \%$ $\mathrm{MeOH}-\mathrm{CH}_{2} \mathrm{Cl}_{2}$ ). The fraction eluting at $\mathrm{Rf} \sim 0.2$ was concentrated to afford $1 \mathrm{mg}$ of $\mathbf{5}$ as gum.

\section{Ergosterol Peroxide (6)}

Ergosterol and its peroxide are components of the fungal cell wall. The peroxide was isolated from a series of cultures and identified by direct comparison with an authentic sample obtained from our collection. The biological data reported here is from a sample from our collection.

\section{Fermentation and Isolation of 7}

The producing organism, an unidentified Coelomycete (JP4567) was isolated from live leaves of Sweet gum collected in New Jersey and was grown on FFL media. A 2-liter broth was extracted with 2 liters MEK and the extract $(1.6 \mathrm{~g})$ was chromatographed on 1 liter of Sephadex LH 20 in $\mathrm{MeOH}$. A 2/5th portion of an $800 \mathrm{mg}$ active fraction was chromatographed on a similar Zorbax $\mathrm{RX} \mathrm{C}_{8}$ column eluting with a 30 minutes gradient of $20 \sim 80 \%$ aqueous $\mathrm{CH}_{3} \mathrm{CN}+0.1 \%$ TFA with a hold for 20 minutes at a flow rate of $8 \mathrm{ml} / \mathrm{minute}$. The active fraction $(96 \mathrm{mg}$ ) eluted with $80 \% \mathrm{CH}_{3} \mathrm{CN}$ and was further chromatographed on the same column with a 30 minutes gradient of $80 \sim 90 \%$ aqueous $\mathrm{CH}_{3} \mathrm{CN}$ at a flow rate of $8 \mathrm{ml} /$ minute eluting active compound at 36 40 minutes which upon lyophilization afforded $14 \mathrm{mg}$ of 7 as a gum.

\section{LXR-SPA Binding Assays}

LXR scintillation proximity assay (LXR-SPA) was performed using the GST-LXR ligand binding domain (LBD) of the $\alpha$ or $\beta$ receptor and the ligand $\left[{ }^{3} \mathrm{H}_{2}\right] \mathrm{F}_{3}$-methyl AA (12) as detailed by Menke et al [14].

\section{Coactivator-association Assays}

The agonist activity of compounds were measured in an in vitro coactivator association assays. In this assay, the association of recombinant steroid receptor coactivator 1 (SRC1) coactivator protein with recombinant LXR $\alpha$ and $\beta$ ligand binding domains were measured using a HTRF assay as described earlier [14].

\section{LXR $\alpha$ and $\beta$ Cell Based Transactivation Assay}

Cell-based transactivation assay using a chimeric LXR constructs were used to measure the $\operatorname{LXR} \alpha$ and/or $\beta$ agonist or antagonist functional activity in HEK-293 cells. This assay uses fusion proteins with the yeast Gal4 DNA binding domain connected to the hinge region and the LBD domain of either LXR receptors and has been previously described [14, 25].

Acknowledgements Authors thank Marta Arocho and Pilar Hernandez for sample preparation for screening.

\section{References}

1. Willy PJ, Umesono K, Ong ES, Evans RM, Heyman RA, 
Mangelsdorf DJ. LXR, a nuclear receptor that defines a distinct retinoid response pathway. Gene Dev 9: 1033-1045 (1995)

2. Miyata KS, McCaw SE, Patel HV, Rachubinski RA, Capone JP. The orphan nuclear hormone receptor LXRalpha interacts with the peroxisome proliferator-activated receptor and inhibits peroxisome proliferator signaling. J Biol Chem 271: 9189-9192 (1996)

3. Shinar DM, Endo N, Rutledge SJ, Vogel R, Rodan GA, Schmidt A. NER, a new member of the gene family encoding the human steroid hormone nuclear receptor. Gene 147: 273-276 (1994)

4. Repa JJ, Mangelsdorf DJ. The liver X receptor gene team: potential new players in atherosclerosis. Nat Med 8: 1243-1248 (2002)

5. Janowski BA, Willy PJ, Devi TR, Falck JR, Mangelsdorf DJ. An oxysterol signalling pathway mediated by the nuclear receptor LXR $\alpha$. Nature 383: 728-731 (1996)

6. Lehmann JM, Kliewer SA, Moore LB, Smith-Oliver TA, Oliver BB, Su JL, Sundseth SS, Winegar DA, Blanchard DE, Spencer TA, Wilson TM. Activation of the nuclear receptor LXR by oxysterols defines a new hormone response pathway. J Biol Chem 272: 3137-3140 (1997)

7. Janowski BA, Grogan MJ, Jones SA, Wisely GB, Kliewer SA, Corey EJ, Mangelsdorf DJ. Structural requirements of ligands for the oxysterol liver X receptors LXRalpha and LXRbeta. Proc Natl Acad Sci USA 96: 266-271 (1999)

8. Fu X, Menke JG, Chen Y, Zhou G, MacNaul KL, Wright SD, Sparrow CP, Lund EG. 27-Hydroxycholesterol is an endogenous ligand for liver $\mathrm{X}$ receptor in cholesterol-loaded cells. J Biol Chem 276: 38378-38387 (2001)

9. Joseph SB, McKilligin E, Pei L, Watson MA, Collins AR, Laffitte BA, Chen M, Noh G, Goodman J, Hagger GN, Tran J, Tippin TK, Wang X, Lusis AJ, Hsueh WA, Law RE, Collins JL, Willson TM, Tontonoz P. Synthetic LXR ligand inhibits the development of atherosclerosis in mice. Proc Natl Acad Sci USA 99: 7604-7609 (2002)

10. Singh SB, Ondeyka JG, Liu W, Chen S, Chen TS, Li X, Bouffard A, Dropinski J, Jones AB, McCormick S, Hayes N, Wang J, Sharma N, MacNaul K, Hernandez M, Chao YS, Baffic J, Lam MH, Burton C, Sparrow CP, Menke JG. Discovery and development of dimeric podocarpic acid leads as potent agonists of liver X receptor with HDL raising activity in mice and hamsters. Bioorg Med Chem Lett 15 : 2824-2828 (2005)

11. Herath K, Jayasuriya H, Ondeyka JG, Guan Z, Borris RP, Stijfhoorn E, Stevenson D, Wang J, Sharma N, MacNaul K, Menke JG, Ali A, Schulman MJ, Singh SB. Guttiferone I, a new prenylated benzophenone from Garcinia humilis as a liver X receptor ligand. J Nat Prod 68: 617-619 (2005)

12. Jayasuriya H, Herath KB, Ondeyka JG, Guan Z, Borris RP, Tiwari S, de Jong W, Chavez F, Moss J, Stevenson DW, Beck HT, Slattery M, Zamora N, Schulman M, Ali A, Sharma N, MacNaul K, Hayes N, Menke JG, Singh SB. Diterpenoid, steroid and triterpenoid agonists of liver $\mathrm{X}$ receptors from diversified terrestrial plants and marine sources. J Nat Prod 2005 (in press)

13. Herath KB, Jayasuriya H, Guan Z, Schulman M, Ruby C, Sharma N, MacNaul K, Menke JG, Kodali S, Galgoci A, Wang J, Singh SB. Anthrabenzoxocinones from Streptomyces sp. as liver X receptor ligands and antibacterial agents. J Nat Prod 2005 (in press)

14. Menke JG, Macnaul KL, Hayes NS, Baffic J, Chao Y-S, Elbrecht A, Kelly LJ, Lam MH, Schmidt A, Sahoo S, Wang J, Wright SD, Xin P, Zhou G, Moller DE, Sparrow CP. A novel liver $\mathrm{X}$ receptor agonist establishes species differences in the regulation of cholesterol 7\{alpha\}-hydroxylase (CYP7a). Endocrinology 143: 2548-2558 (2002)

15. Chobot V, Opletal L, Jahodar L, Patel AV, Dacke CG, Blunden G. Ergosta-4,6,8,22-tetraen-3-one from the edible fungus, Pleurotus ostreatus (oyster fungus). Phytochem 45: 1669-1671 (1997)

16. Raederstorff D, Rohmer M. The action of the systemic fungicides tridemorph and fenpropimorph on sterol biosynthesis by the soil amoeba Acanthamoeba ployphaga. Eur J Biochem 164: 421-426 (1987)

17. Raederstorff D, Rohmer M. Sterol biosynthesis via cycloartenol and other biochemical features related to photosynthetic phyla in the amoebe Naegleria lovaniensis and Naegleria gruberi. Eur J Biochem 164: 427-434 (1987)

18. Akihisa T, Kokke WCMC, Kimura Y, Tamura T Isokarounidiol [D:C-Friedooleana-6,8-diene-3alpha,29-diol]: the first naturally occuring triterpene with a delta6,8conjugated diene system. Iodine-mediated dehydrogenation and isomerization of its diacetate. J Org Chem 58: 1959-1962 (1993)

19. Bisseret P, Adam H, Rohmer M. Structure elucidation of ring $\mathrm{B}$ aromatic sterols of the soid amoeba Acanthamoeba polyphaga. J Chem Soc Chem Commun 693-695 (1987)

20. Ponce MA, Ramirez JA, Galagovsky LR, Gros EG, ErraBalsells R. A new look into the reaction between ergosterol and singlet oxygen in vitro. Photochem Photobiol Sci 1: 749-756 (2002)

21. Akihisa T, Shimizu N, Tamura T, Matsumoto T. (24S)14alpha,24-dimethyl-9beta,19-cyclo-5alpha-cholest-25-en3beta-ol: A new sterol and other sterols in Musa sapientum. Lipids 21: 494-497 (1986)

22. Akihisa T, Kimura Y, Kokke WCMC, Takase S, Yasukawa K, Jin-Nai A, Tamura T. 4-Epicycloeucalenone and 4epicyclomusalenone: Two 3-oxo-28-norcycloartanes from fruit peel of Musa sapientum L. Chem Pharm Bull 45: 744-746 (1997)

23. Spencer TA, Li D, Russel JS, Collins JL, Bledsoe RK, Consler TG, Moore LB, Galardi CM, McKee DD, Moore JT, Watson MA, Parks DJ, Lambert MH, Willson TM. Pharmacophore analysis of the nuclear oxysterol receptor LXRa. J Med Chem 44: 886-897 (2001)

24. Peláez F, Collado J, Arenal F, Basilio A, Cabello MA, Díez MT, B., GJ, González Del Val A, González V, Gorrochategui J, Hernandez P, Martín I, Platas G, Vicente F. Mycol Res 
102: 755-761 (1998)

25. Sparrow CP, Baffic J, Lam M-H, Lund EG, Adams AD, Fu, X, Hayes N, Jones AB, Macnaul KL, Ondeyka J, Singh S, Wang J, Zhou G, Moller DE, Wright SD, Menke JG. A potent synthetic LXR agonist is more effective than cholesterol loading at inducing ABCA1 mRNA and stimulating cholesterol efflux. J Biol Chem 277: 10021-10027 (2002) 